\title{
Differentiating Egyptian Entrepreneurs Small and Micro Business Owner-Managers According to the Entrepreneurial Traits
}

\author{
Dr. Amr Alaaeldin Zidan \\ Associated Professor of Business Administration \\ Faculty of Technology and Development \\ Zagazig University \\ Arab Republic of Egypt \\ a.zidan16@yahoo.com
}

\begin{abstract}
Purpose: to explore the entrepreneurial profile of the Egyptian entrepreneurs, small and Micro business owner-managers. The research, also, permit further understanding of entrepreneurial personality characteristics of the Egyptian entrepreneurs.

Research Design: In this study, six traits, namely locus of control, independence, network, wealth valuation, optimism and innovativeness, are used to define the entrepreneurial profile of the Egyptian entrepreneurs. Six hypotheses were formed. The EFA and CFA were used. Entrepreneurial traits resulting from Factor analysis were examined according to MANOVA Test.

Sample and Data: A convenience and judgemental sample of 607 Egyptian entrepreneurs and business owner-managers was selected from the Egyptian private sector population and a questionnaire was used for data collection.

Findings: The research results indicated that the Egyptian Entrepreneurs and Owner-Managers have the following entrepreneurial traits, respectively: Wealth, Innovation, Network, Optimism, Independence, and Locus of control. The Egyptian Entrepreneurs and Owner-Managers have a paragmatic and realistic entrepreneurial personality.

Originality: This study contributes to understanding the Egyptian entrepreneurial society. It also explores the paragmatic and realistic nature of the Egyptian entrepreneurs.

Research Limitation/Implication: Conclusions are limited by the non-propability sample (a convenience and judgemental sample). Rather, the results enforce the idea that psychological characteristics (trait approach) are still valid to portray the profile of the Egyptian entrepreneurial society. The results can be used by the Egyptian decision makers to articulate the entreepreneurial policies and entrepreneurship education programs.
\end{abstract}

Keywords: Entrepreneurial Traits Approach, Entrepreneurs, Small and Micro-Business, Owner-Managers, Egyptian Private Sector.

\footnotetext{
* This article was submitted in December 2020, accepted for publishing in January 2021.

(c) Arab Administrative Development Organization- League of Arab States, 2020, pp 357-370،
} 


\section{Introduction}

It is generally acknowledged that at the center of the entrepreneurial process stands the individual entrepreneur as key agent. Research on personality and entrepreneurship has focused on two broad research questions: Why do some people but not others become entrepreneurs? Why do some people make more successful entrepreneurs than others? The personality approach provided the impetus for substantial research in the 1960s and 1970s, with research on need for achievement (Nach; McClelland, 1961), the most frequently studied personality characteristic, peaking in the 1980s till 2000s. Since then, an extensive body of research indicates that the psychological character of entrepreneurs strongly affects their behavior and actions in the entrepreneurial process (Obschonka and Stuetzer, 2017; Omorede, Thorgren and Wincent, 2015; Hisrich, Langan-Fox and Grant, 2007; Rauch and Frese, 2007).

Much research in the field of entrepreneurship has sought to uncover a set of psychological characteristics that set entrepreneurs apart from other members of the population. This stream of research is generally known as the trait approach to entrepreneurship (Gilmore, Carson and O'Donnell, 2004). the trait approach has been criticized because such traits have been found to only bear a weak relationship to Entrepreneurial Intentions and behaviour, several scholars have indeed argued that the trait approach can not simply be dismissed. They, also, admit that personality may still play an important role in the entrepreneurial process and creation of new ventures and entrepreneurship research needs to analyze the entrepreneur's personality as seriously as those that have researched employees' personality (Karimi, Biemans, Mahdei, Lans, Chizari and Mulder, 2017; Rauch and Frese, 2007).

Some scholars assert that the entrepreneur is a particular personality type (Gartner, 1988). Thus, majority of entrepreneurship literature aimed to enumerate a set of characteristics describing entrepreneur. The Trait approach, aims to define and measure entrepreneurship using a series of personality traits and recurrent behaviours most associated with successful entrepreneurs. These personality traits are widely argued as essential personal "ingredients" that an entrepreneur needs to be successful (Smith, Bell and Watts, 2014).The study of entrepreneurship from an individual or "traits" perspective focuses on the attributes of the person and how these attributes might be related to exploiting opportunities which others either do not recognize or choose not to pursue. Psychological characteristics form the underlying base for an individual to transform into a founder of an enterprise (Begley and Boyd, 1987). Such characteristics have been studied to distinguish entrepreneurs from non-entrepreneurs (Davidsson, 1995).

According to Rauch and Frese (2007), links between the personality traits, business startup and success need to be explicitly conceptualized. True effects will be underestimated if one does not select the appropriate personality traits that are more likely to be predictive of entrepreneurship. Traits that are more likely to predict entrepreneurial behaviour are those traits that match personality with work characteristics, on one hand, and match personality with work context, on the other hand.

The recent shift from a managed economy towards an entrepreneurial economy is reflected in the increasing number of Micro, Small and Medium Enterprises (MSMEs). MSMEs play a pivotal role as engines of economic growth and as a vehicle of employment creation, poverty alleviation and economic development in both developed and developing economies. This role is widely acknowledged and has been a focus of academic research and policy making for decades (Mabhungu1 and Poll, 2017; Gherhes, Williams, Vorley and Vasconcelos, 2016). MSMEs are treated as the anchors of Egyptian economy. They account for approximately (99\%) of the enterprise population in Egypt (Achy and Slim, 2016).

The structure of the Egyptian economy has changed fundamentally as a result of the reforms introduced and pursued since 1974. This transition, "from the Nasser period to al-infitah ('economic opening') by Anwar Elsadat", has underpinned and generated the rapid and sustained growth of the Egyptian economy.There has been a re-alignment of the economy away from planned decision-making by central government to a greater 
emphasis on economic liberalisation and competition. Since reaching a standby agreement with the International Monetary Fund (IMF) in May 1991, in particular, the Egyptian government has accelerated the pace of economic liberalization and introduced a broad and ambitious programme to privatize state-owned enterprises across a range of economic industries (Gray, 1998).

Despite efforts to encourage unleash Egyptian young and dynamic entrepreneurial talents to make self employment the first career choice, the Egyptian entrepreneurial climate faces the following challenges: (Abdelbary, 2019; Creative Associates International, 2014)

- Weak Entrepreneurship: Entrepreneurs tend to be unstructured and they use their business as a primary source of income. They don't have the ambition to grow with their business to the next level. The entrepreneurial mindset may be part of the cause.

- Lack of innovation and potential among Egyptian entrepreneurs, and as a result they need to learn the entrepreneurial skills.

- It is rare to find entrepreneurs who are taking advantage of change to create innovative, valuable products or business models that can lead Egypt into new growth markets.

- Participation of Egyptian women to start their own businesses, in the newly rising entrepreneurship ecosystem still remains lower than expected. Almost $86 \%$ of early-stage entrepreneurs in Egypt are led or owned by men, while women comprise the remaining $14 \%$.

- Egyptian entrepreneurs are located across different urban and rural regions, yet highly dense within Greater Cairo.

- MSME are very large in numbers, diverse in type of business and are spread across remote geographies of a vast country.

- A large portion of SMEs are informal and not registered with the formal systems of MSME. The reason behind this is to run away from paying taxes.

The mentioned challenges characterize the Egyptian economy were the impetus to study the psychological traits of the Egyptian entrepreneurs and small/micro business owner-managers in a post-socialist environment. The fundamental questions that have yet to be answered satisfactorily are whether smaller firms' owner-managers are entrepreneurs and whether there are specific characteristics, which separate entrepreneurs from smaller business owner-managers (Beaver and Jennings, 2005). As the owner-manager is the central person in control in micro business (to a greater extent than in SMEs), this study aimed to investigate the significant differences regarding entrepreneurial traits among entrepreneurs and owner-managers in the Egyptian context. As a result, the study sought to achieve the following objectives:

- To identify the psychological traits, characterize the Egyptian entrepreneurs and small/micro business Owner-managers,

- To differentiate among the Egyptian entrepreneurs and small/micro business Owner-managers in terms of psychological traits.

\section{Literature Review and Research Hypotheses:}

The literature review of this study is threefold. First, MSMEs in the world and Egyptian context is addressed. Secondly, differentiation between entreprenurs and owner-managers is discussed. Thirdly, literature on the perspective of the entrepreneurial trait approach is reviewed.

\section{MSMEs in the World and Egyptian Context:}

MSMEs often acting as a nursery of entrepreneurship. They also play a key role in the development of the economy with their effective, efficient, flexible, and innovative entrepreneurial spirit. The MSME sector 
contributes significantly to the economic indices, such as manufacturing output, employment and exports, and impetus to a highest employment growth as well as accounts for a major share of industrial production and exports. The credibility of MSMEs sector across the world is that of an engine of economic growth; it's a key instrument for promoting equitable development. The major advantage of the sector is its employment potential at low capital cost. The labour intensity of the MSMEs sector is much higher than that of large enterprises (Ibrahim, 2018).

MSMEs constitute more than $90 \%$ of total enterprises in most of the economies. For example, in the European Union (EU), policy makers consider MSMEs as the backbone of the economy and their support as key to ensure economic growth, innovation, job creation and social inclusion. MSMEs account for (60\% to $70 \%$ ) of jobs in most OECD countries and are broadly considered an important source of job creation and a major channel for poverty alleviation (Ayadi and Sessa, 2017). In Japan and China, SMEs contribute more than $50 \%$ of the country's GDP, while in Japan, Taiwan, Korea, Germany, and China; SMEs contribute more than (70\%) of the employment opportunity (Ong and Ismail, 2012). All these figures reflect the importance of MSMEs both in developed and developing economies (Wang, 2016).

Egypt has a long journey to encourag business start up among young Egyptian. These efforts campaign the economic reform during the last three decades. This journey can be classified according to the steges of the Egyptian economic reform experiment into the following stages: (Abdel Bary, 2019; Abou Elseoud, Kreishan and Ali, 2019; Zaki and Zeini, 2019)

- The first stage began in 1990, when the Egyptian government undertakes extensive economic restructuring under the supervision of the International Monetary Fund (IMF). Egypt agreed and entered an IMF-sponsored Economic Reform and Structural Adjustment Plan (ERSAP) in 1991.

- By 1991, Egyptian government established the Social Fund for Development to facilitate business start up for the Egyptian youth. It was, also, an important aspect of the Egyptian Privatization Program. In June 1998, The Government of Egypt sought to support SMEs sector by adopting the "National Policy for SME Development", Followed by issuing the law (141/2004) that enhanced SMEs' through financial and technical support.

- In 2008, the Central Bank of Egypt (CBE) also launched an initiative, as an integral part of the Second Phase of the Banking Sector Reform Programme (2008-2011), to enhance SMEs access to finance and banking services. In 2016 the CBE announced that credit to SMEs must account for at least $20 \%$ of any commercial bank's loan book by 2020 . This stimulus package could amount to an injection of $\$ 25 \mathrm{bn}$ at highly attractive rates of less than $5 \%$, which is significantly lower than the CBE's main credit rate of $11.25 \%$.

- In 2017, the Egyptian Micro, Small and Medium Enterprise Development Agency (MSME) was established according to a decree issued by the prime minister. MSME classified the enterprises under the following four categories according to the turnover, capital and employment size: micro-sized enterprises, small-sized enterprises, medium-sized enterprises and entrepreneurship (innovative enterprises). The 2018 MSME's national strategy, as a part of the sustainable development strategy, aims to improve the legislative and regulatory environment, reducing administrative burdens, simplifying the regulatory environment for projects and creating a range of financial and non-financial incentives to encourage the informal sector to join the formal sector. In addition, it aims to promote entrepreneurship and to develop a culture of entrepreneurship - including risk tolerance - as well as to provide all the training and incubation programmes to help start new ventures and improve skills, through establishing business incubators and innovation hubs all over Egypt (Egypt Vision, 2030).

Accordingly, MSMEs are treated as the anchors of Egyptian economy. In Egypt, MSMEs are very large in numbers, diverse in type of business and are spread across remote geographies of a vast country. A large portion of the MSMEs are informal and not registered with the formal systems of MSME. It will require sig- 
nificant changes in philosophy and approach to be able to develop and deliver a new wave system which facilitates their development and seize the emerging domestic and global opportunities. This will help unleash a young and dynamic entrepreneurial talent in Egypt who will be willing to make selfentrepreneurship the first career choice and develop growth companies (Abdelbary, 2019).

The estimated number of MSMEs at the end of 2011 totaled about (3.04) million establishments, with average enterprise size equal to (2.63) workers generating the bulk of employment and income opportunities. This kind of enterprises account for approximately (99\%) of the enterprise population in Egypt, and they represent between ( $86 \%$ ) and (97\%) of all formal sector and contribute to nearly $80 \%$ of GDP and $75 \%$ of total employment in Egypt (Ayadi and Sessa, 2017; Creative Associates International, 2014). The available data shows that $(91 \%)$ of these enterprises are micro firms (those with fewer than ten employees), while the small and medium enterprises represent (8\%) of total and large firms less than (1\%) (CAPMAS, 2018).

Such figures on MSMEs' sector magnitude exceed those of most countries in the MENA region and compare with those of East and Southeast Asia and Sub- Saharan Africa. In terms of policymaking, such figures indicate that micro and small enterprises need to be at the heart of any national strategy for poverty alleviation and job creation (Achy and Slim, 2016).

\section{Entrepreneurs and Owner-managers (Independent Variables):}

To discuss the definitions of the term "entrepreneur' is beyond the scope of this study. Instead, the researcher aimed at differentiates between entrepreneurs and owner-managers of micro and small business according to the following definitions which, I think, satisfy the Egyptian context: (Carland et al., 1984)

- Small business owner is an individual who establishes and manages a business for the principal purpose of furthering personal goals. The business must be the primary source of income and will consume most of one's time and resources. The owner perceives the business as an extension of his or her personality, intricately bound with family needs and desires.

- Entrepreneur is an individual who establishes and manages a business for the principal purposes of profit and growth. The entrepreneur is characterized principally by innovative behavior and will employ strategic management practices in the business.

Schumpeter (1934) was among the first to identify the entrepreneur as an entity worthy of study, distinct from business owners and managers. He described entrepreneurs as individuals whose function was to carry out new combinations of means of production. Entrepreneurs, therefore, warranted study independent of capitalists, owner-managers and business managers (Carland et al., 1984). Vesper (1980) introduced a continuum along which several "types" of entrepreneurs exist. His first type, the "Solo Self-Employed Individual," is essentially what is treated here as the small business owner-manager, but not truly an entrepreneur in the Schumpeterian sense because a new combination is not created (Carland, et al., 1984). Later, Carland et al. (1984) distinguished entrepreneurs, business owners focusing on profit and growth, from small business owners who focus on producing family income. Bygrave (1989) refers to "mega- and micro-entrepreneurs": "Mega-entrepreneurs start businesses that intend to grow big. Micro-entrepreneurs start businesses that remain small". Entrepreneurship, therefore, can be conceptualized along a continuum ranging from entrepreneur at one end to administrator at the other (Hisrich et al., 2007).

The most important qualitative characteristic of small businesses is the crucial annex prominent role of the entrepreneur, also known as the owner-manager of the firm: he is both the daily manager and the (major) owner of the firm. The entrepreneur may also be the founder of the firm. This qualitative characteristic is one of the most distinguishing qualitative characteristics of a small business, as large firms in general have a board, a management team, multiple owners/shareholders, and a shareholder meeting. So, the en- 
trepreneur of the small business is in daily charge (through management) and in final charge (through ownership) of the firm. As a result, SMEs are influenced in their business approach by the dominant presence of owner-managers. Accordingly, if you want to understand the small business, you should first understand the entrepreneur; otherwise you will never understand the firm (Masurel and Masurel, 2019).

The focal role of the owner-manager has long been recognized in the small business and entrepreneurship literature. Small business owners are often described as being "craftsmen" or "lifestyle entrepreneurs", and their family business was characterized to be risk averse because the entrepreneur must prioritize the possibility of making a living for his or her family ahead of potential growth of firm. Those entrepreneurs start their businesses in areas that reflect their desired living environment, develop businesses closely related to areas of personal interest, and keep their businesses small (Jaouen and Lasch, 2015; Sjgren, Puumalainen and Syrja, 2011).

In addition, small business is the result of the Owner-manager's life project. In this sense, this venture is part of a life plan: the concrete means for achieving the entrepreneur's personal objectives. Kisfalvi (2002) suggested that the strategy making processes of such entrepreneurs primarily reflect their particular set of life issues. This suggestion is particularly relevant for family firms, in which entrepreneurial behaviour and family issues frequently are deeply embedded (Jaouen and Lasch, 2015).

Finally, we turn to micro business; Cyr, Meier and Pacitto (2011) call them Very Small Enterprises (VSE) owner-managers. Although micro business owner-managers do have behaviours and practices that go against the prescriptions of generally accepted management models, the underlying reasons for these behaviours have too often been sought in attitudinal variables grounded in the values and beliefs of the owner-manager rather than in their practical business reasons. As a result, what is needed in this context is a much better understanding of the inner workings of (VSEs) from the owner-manager's point of view. The management system of these firms is poorly understood, notably because it is usually embodied in the physical person of their owner-managers who, as a rule, are generally not inclined to set up formal, documented management systems. If the need arises, these actions are then rationalised into formal decisions (Cyr et al., 2011).

The entrereneurs and owner-managers of the Egyptian enterprises represent the independent variables of this study. These variables were measured as dummy variables as follows: Owner-managers of micro business $=0$, Owner-managers of small business $=1$ and Entrepreneurs $=2$.

\section{Entrepreneurial Traits and Characteristics (Dependent Variable):}

Researches on psychological forefront has emphasized on personality traits of entrepreneurs. Three pertinent theories are of McClelland, Schumpeter and Rotter. Notably, McClelland (1961) was at the vanguard and believed that a high "need for achievement", "risk-taking or propensity for innovation" and "need for novelty" characterized these individuals. Along with him Rotter (1966) developed the concept of Locus of Control. Schumpeter (1967) has claimed that innovation is an important characteristic of an entrepreneur (Chatterjee and Das, 2015; Lee-Ross, 2015).

As a result, the three basic psychological attributes "Big Three" (need for achievement; risk-taking propensity; and locus of control) became the often used in the literature to differentiate between entrepreneurs and non-entrepreneurs. Furthermore, most of the research within the entrepreneurship literature has concentrated on them (Johnson et al., 2003).

Subsequently, many researchers followed them. Earlier Begley and Boyd (1987) included "tolerance for ambiguity" inherent in the entrepreneurial environment as another characteristic. In the study by Stewart, Jr., Watson, Carland and Carland, (1998), need for achievement, risk taking propensity and innovation 
have been used as determinants for distinguishing "entrepreneurs" from "corporate managers" and "small business owners". Mueller and Thomas (2000) add "locus of control" as a personal characteristic. In the study by Entrialgo, Farnandiez and Vazquez, (2000) locus of control, need for achievement and tolerance for ambiguity are regarded as the determinants of the tendency for entrepreneurship. Other studies used six personality traits, namely, need for achievement, locus of control, risk taking propensity, tolerance for ambiguity, innovativeness and self-confidence to define the entrepreneuiral profile of university students (Chaudhary, 2017; Gurol and Asten, 2006; Koh, 1996) in different countries. Bygrave and Hofer (1991) stated that the major psychological dimensions associated with entrepreneurship process are need for achievement, locus of control, risk-propensity, self-efficacy, tolerance for ambiguity, innovativeness, independence and autonomy and optimism.

Despite the above debate, the achievement motivation may not be the most important variable for predicting the likelihood of starting a business. In addition, achievement motivation was not a significant factor among students who intended to become entrepreneurs and those who did not, or between those who indicated entrepreneurial interest through the choice of majors (Pillis and Reardon, 2007; Stewart et al., 1998).

Along with the same perspective, the entrepreneurial literature, however, does not support risk-taking as characteristic of entrepreneurs. Some studies have indicated no significant differences in the risk-taking propensities of entrepreneurs as compared with the general population, or to managers. Yet, most of the empirical studies (Raposo et al., 2008; Pillis and Reardon, 2007; Gilmore et al., 2004; Stewart et al., 1998; Brockhaus, 1980) reported that small business entrepreneurs do not have positive attitudes towards risk and they do not consider themselves as risk takers, nor do they seem to differ from other groups. Owner-managers, also, employed various strategies to manage and minimize the risk associated with these activities. Having gone through and survived the difficult and uncertain start-up years, these owner-managers show reluctance to involve themselves in activities that may jeopardize the relative security that they worked so hard to attain. Furthermore, risk-taking propensity does not distinguish between successful and unsuccessful entrepreneurs.

Accordingly, the theoretical model of the current study consists of six psychological characteristics. They are locus of control, independence, network, wealth valuation, optimism and innovativeness.

These psychological characteristics have been considered in this study because of tow reseaons: first, its relationship with entreprenurship has been evident in literatures. Second, they have been given a fair recognition in previous research. These variables were measured using five points (1-5) likert scale where (1) refers to "completely disagree" and (5) refers to "completely agree". The items concerning each variable were interspersed throughout the questionnaire in order to avoid bias in responses. The items used to measure these characteristics were as follows: wealth (7 items), innovation (8 items), networking (5 items), independence (6 items), optimism (5 items), LOC (9 items). These measures had been created and adapted according to the empirical literature of entrepreneurial traits (Adomako et al., 2016; Nasip, Amirul, Sondoh, Jr. and Tanakinjal, 2017; Pedrini, Langella and Molteni, 2017; Bello and Aliyu, 2016; Lee-Ross, 2015; Ebbers, 2013; Dinis, Paco, Ferreira, Raposo and Rodrigues, 2013; Koh, 1996; Davidsson, 1995; Robinson, Simpson, Huefner and Hunt, 1991).

The following lines present a review of literature around each of the aforemensioned dimensions followed by the research hypotheses.

Locus of control (LOC): According to Julian Rotter (1966), the concept of locus of control refers to a person's generalized belief over control of his or her own destiny. There are two types of locus of control: external control and internal control. Those who accredit control of events and destiny to themselves are likely to have an internal locus of control. People who accredit control of forces beyond their control are said 
to have an external locus of control. Internal locus of control is related to entrepreneurship because owners must believe that their own actions determine the rewards (business outcomes) they obtain. Many literature studies have revealed through empirical findings that internal locus of control is an entrepreneurial characteristic that has the major drive toward entrepreneurial activity (Chatterjee, Das and Srivastava, 2019).

- H1a. Egyptian entrepreneurs will demonstrate a higher level of locus of control than will small business owner-managers.

- H1b. Egyptian entrepreneurs will demonstrate a higher level of locus of control than will micro business owner-managers.

- H1c. Egyptian small business owner-managers will demonstrate a higher level of locus of control than will micro business owner-managers.

Innovativeness: Innovativeness is perceived as an important aspect of the entrepreneurial process. Innovation has been one of the core concepts of Schumpeter's approach to entrepreneurship. According to Schumpeter (1990), an entrepreneur is simply an innovator converting ideas into concepts. Innovativeness assumes a person's willingness and interest to look for novel ways of action. Various research works on entrepreneurship have commonly mentioned innovativeness as a distinct characteristic of the entrepreneur. Some researchers claimed that innovation is a primary intention in putting up a business venture. Entrepreneurs were reported to be more innovative than the non-entrepreneurs (Chatterjee, et al., 2019; Gurol and Atsan, 2006; Thomas and Mueller, 2000; Koh, 1996).

- H2a. Egyptian entrepreneurs will demonstrate a higher level of innovativeness than will small business owner-managers.

- H2b. Egyptian entrepreneurs will demonstrate a higher level of innovativeness than will micro business owner-managers.

- H2c. Egyptian small business owner-managers will demonstrate a higher level of innovativeness than will micro business owner-managers.

Networking: Social networking, which is the tendency to connect and interact with other people, is a social behavior but it also may be viewed as a psychological or personality variable because Maslow (1970) identified the desire for social interaction (i.e. "belongingness") as an essential psychological need. Social networking is useful in entrepreneurial process, to obtain information and advice. Entrepreneurs are networking with others to get advice for their business. Focusing on social network analysis turns attention to relationships between entrepreneurs and others that provide the resources that are important in establishing a business. Students who are involved in entrepreneurial model have a high social networking value. Social networking also plays an important role in developing entrepreneurial intention (Bertelsen, Ashourizadeh, Jensen, Schøtt and Cheng, 2017; Kusmintarti, Thoyib, Maskie and Ashar, 2016; Taormina and Lao, 2007; Greve and Salaff, 2003).

- H3a. Egyptian entrepreneurs will exhibit a hiegher level of networking tendency than will small business owner-managers.

- H3b. Egyptian entrepreneurs will exhibit a hiegher level of networking tendency than will micro business owner-managers.

- H3c. Egyptian small business owner-managers will demonstrate a higher level of networking tendency than will micro business owner-managers.

Wealth:

The assumption that people start new ventures as a way to increase their personal wealth underlies much of the research in entrepreneurship. The goal of personal wealth is assumed paramount. Thus, the terms "wealth" and "entrepreneurship" are, normally, linked in the minds of many people, including researchers, in capitalist societies. Amit, Maccrimmon, Zietsma, and Oesch (2000) disgussed the role that the 
desire for wealth attainment plays in start-up decisions made by entrepreneurs. They, also, assumed that money matters more to entrepreneurs than to non-entrepreneurs because of the traditional association between entrepreneurship and wealth. On the other hand, Davidsson (1995) stated that the prospect of making more money typically ranks low in entrepreneurs' stated motivations for founding their own firms.

- H4a. Egyptian entrepreneurs will exhibit a hiegher level of wealth valuation tendency than will small business owner-managers.

- H4b. Egyptian entrepreneurs will exhibit a hiegher level of wealth valuation tendency than will micro business owner-managers.

- H4c. Egyptian small business owner-managers will demonstrate a higher level of wealth valuation tendency than will micro business owner-managers.

Optimism: Optimism is the tendency to have a favorable outlook on life. Optimism well describes entrepreneurial attitude. People who have already made the commitment to become entrepreneurs showed a remarkable degree of optimism. Most entrepreneurs are optimistic although there are variations. Optimism is a trait that generates a confidence that positive outcomes will occur. Optimism researchers have shown that optimists are more resilient and biased towards action. That is, optimism is a positive, motivating force. Importantly for entrepreneurs, optimism also promotes persistence, commitment, and an ability to influence others to commit to the venture. On the other hand, optimism has also been a negative force among entrepreneurs resulting in their tendency to create ventures with a high risk of failure (Chatterjee and das, 2015; Liang and Dunn, 2014; Trevelyan, 2008; Taormina and Lao, 2007).

- H5a. Egyptian entrepreneurs will exhibit a hiegher level of optimism tendency than will small business owner-managers.

- H5b. Egyptian entrepreneurs will exhibit a hiegher level of optimism tendency than will micro business owner-managers.

- H5c. Egyptian small business owner-managers will demonstrate a higher level of optimism tendency than will micro business owner-managers.

Independence: Being independent and act autonomously, and not being dependent on others for accomplishing any task is an important characteristic of an entrepreneur. Need for autonomy is associated with entrepreneurs' avoidance of restrictive environments; they prefer to make decisions independent of supervisors, to set their own goals and develop their own plans of actions, and to control goal achievement themselves. People high in need for autonomy want to be in control, they avoid the restrictions and rules of established organizations, and thus, choose the entrepreneurial role (Rauch and Frese, 2007). Many researches have showed that independence is a necessary element in entrepreneurial role. Hisrich (1985) suggested that one of the prime factors for starting a business was a desire to be independent.

- H6a. Egyptian entrepreneurs will display a hieger level of independence motivation than will small business owner-managers.

- H6b. Egyptian entrepreneurs will display a hieger level of independence motivation than will micro businessowner-managers.

- H5c. Egyptian small business owner-managers will demonstrate a higher level of independence motivation than will micro business owner-managers.

After articulating the research hyposeses, it was necessary to conduct exploratory factor analysis (EFA) to uncover the underlying factor structure and the distinctiveness of latent variables (entrepreneurial traits). $\mathrm{KMO}$ value was computed to check the measure of sampling adequacy. Bartlett's test of sphericity was used to test the significance of correlation among all factors. Principal Components Analysis (PCA) with Varimax 
rotation method has been conducted as the extracting method for each group of the defined model. The items which loaded weakly $(<0.5)$ or cross loaded $(\geq 0.5)$ were deleted.

The results showed that the KMO value $(>0.6)$ was $(0.812)$, which confirmed that factor analysis was likely to generate satisfactory results. The value of Bartlett test was 2471.209 ( $d f=231, p=0.001)$. Factor loadings and percent of total explained variance by unidimensional factor extraction, are presented in the Table (1). The rotated factor matrix generated (6) factors all with an eigenvalue over the unit which explain $(52.835 \%)$ of the total variance. As a result, these factors were used as inputs in the subsequent analyses.

\section{Reliability Assessment:}

Reliability refers to the extent to which a measure produces the same results if applied at different times. The reliability of the internal consistency of the scale is evaluated by relying on the Cronbach's alpha coefficient $(\alpha)$. All factors had satisfactory alphas, ranging from (0.535) to (0.739) (for the combined sample). Innovativeness coefficient was the highest one (0.739), followed by Wealth (0.720) and Networking (0.683). Optimism coefficient was the lowest one (0.535). The reliability cofficients are presented on the diagonal of Table (2).

\section{Validity Assessment:}

Validity refers to test the ability of data collection tool (questionnaire) to measure what was designed for it, and to confirm that the sample unit explains all the questionnaire items with the same concept that the researcher intended.

In other words, it indicates the ability of the study tool to measure what is intended to be measured. Validity assessment has been conducted on two stages. In the first stage, the researcher translated the scales from English into Arabic. A first Arabic version of the questionnaire was drafted and, then reviewed by tow professors and number of Egyptian entrepreneurs. Some changes on questionnaire were made to improve its readability, format and relevance of its instruments.

\begin{tabular}{|c|c|c|c|}
\hline Factors & Items & Loadings & TVE \\
\hline \multirow{6}{*}{ Wealth } & $\begin{array}{l}\text { 9-I firmly believe money can solve all peo- } \\
\text { ple's problems }\end{array}$ & 0.685 & \multirow{6}{*}{$11.49 \%$} \\
\hline & $\begin{array}{l}\text { 19- I am Proud of my financial pay, riches and } \\
\text { investments, and let my friends know about them }\end{array}$ & 0.593 & \\
\hline & $\begin{array}{l}\text { 29- Compare to most other people I know; I } \\
\text { think about money much more than they do }\end{array}$ & 0.571 & \\
\hline & $\begin{array}{l}\text { 39- I think that richness is a predictor of the } \\
\text { individual success }\end{array}$ & 0.703 & \\
\hline & 49- I think that fortune is the power & 0.530 & \\
\hline & $\begin{array}{l}\text { 62- Savings is the prerequist for investment } \\
\text { and wealth creation }\end{array}$ & 0.635 & \\
\hline \multirow{3}{*}{ Innovation } & $\begin{array}{l}\text { 47- I get real excited when I think of new } \\
\text { ideas to stimulate my business }\end{array}$ & 0.707 & \multirow{3}{*}{$9.21 \%$} \\
\hline & $\begin{array}{l}56-\text { I believe there are always new and } \\
\text { better ways of doing things }\end{array}$ & 0.758 & \\
\hline & $\begin{array}{l}61-\text { I constantly use the innovative goods } \\
\text { and services }\end{array}$ & 0.757 & \\
\hline \multirow{3}{*}{ Networking } & 17-I am an active networker & 0.769 & \multirow[t]{3}{*}{$8.65 \%$} \\
\hline & 27- I maintain contacts outside my inner circle & 0.724 & \\
\hline & 46-I participate in networking events & 0.591 & \\
\hline \multirow{4}{*}{ Optimism } & $\begin{array}{l}\text { 10- I usually expect the best for me and for the } \\
\text { society }\end{array}$ & 0.576 & \multirow[t]{4}{*}{$7.97 \%$} \\
\hline & 20- I am always optimistic about my future & 0.596 & \\
\hline & 30- I usually expect things to go my way & 0.602 & \\
\hline & $\begin{array}{l}\text { 40- Overall, I expect more good things to } \\
\text { happen to me than bad }\end{array}$ & 0.711 & \\
\hline \multirow{3}{*}{ Autonomy } & 18- I am always looking for independence at work & 0.591 & \multirow{3}{*}{$7.89 \%$} \\
\hline & $\begin{array}{l}\text { 28- I think I've found it harder than others } \\
\text { to let authorities control me }\end{array}$ & 0.749 & \\
\hline & 48- I make my decisions in life by myself & 0.783 & \\
\hline \multirow{3}{*}{ LOC } & 41- My life seems like a series of chance events $₫$ & 0.774 & \multirow{3}{*}{$7.63 \%$} \\
\hline & $\begin{array}{l}\text { 63-The success I have is largely a matter of } \\
\text { chance } ₫\end{array}$ & 0.677 & \\
\hline & $\begin{array}{l}66 \text { - sometimes I feel that I don't have enough } \\
\text { control over the direction my life is taking }{ }^{\circledR}\end{array}$ & 0.721 & \\
\hline TVE & & & $52.835 \%$ \\
\hline
\end{tabular}


In the second stage, confirmatory factor analysis (CFA) was conducted to check the construct validity of the proposed measurement model. The proposed model with a total of six constructs fit the data reasonably well as indicated in figure (1). (CFA) output includes many goodness-of-fit criteria. We did not present all possible fit indices. Rather, we will focus on the key GOF values using our rules of thumb to provide som assessment of it (Hair, Jr., et al., 2010, P. 691). According to the principle of the good model: the value of GFI, $\mathrm{NFI}, \mathrm{RFI}$ and CFI should exceed (0.9); AGFI should exceed (0.8); RMSEA should be no more than 0.08; and the ratio of $\chi 2 / \mathrm{df}$ should be less than (3) to test the fitness of the model (Wu and Chen, 2014).

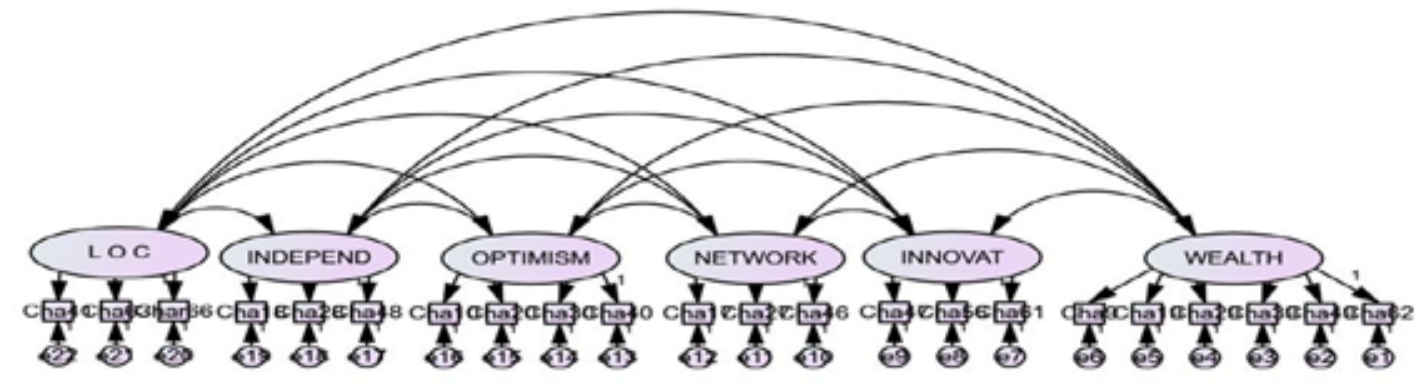

Figure (1): Output of CFA

The results of SEM analysis show that the fitness of the full proposed model met or was close to the criteria, so the model was acceptable as shown in Figures (2).

\begin{tabular}{ccccccccccc}
\hline$\chi^{2}$ & $\mathrm{df}$ & $\chi^{2} / \mathrm{df}$ & Pvalue & $\mathrm{RMR}$ & $\mathrm{GFI}$ & $\mathrm{AGFI}$ & $\mathrm{NFI}$ & $\mathrm{RFI}$ & $\mathrm{CFI}$ & $\mathrm{RMSE}$ \\
\hline 285.784 & 194 & 1.473 & 0.001 & 0.050 & 0.959 & 0.946 & 0.886 & 0.864 & 0.960 & 0.028 \\
\hline
\end{tabular}

Figure (2): Indicators of model fit

Drawing on the six-factor solution, the measurement model used in the present study consists of six dimensions, namely, wealth, innovativeness, networking, independence, optimism and LOC.

\section{Research methodology:}

This section discusses the research methodology undertaken for the study. The section comprises the data collection and a description of the variables used, followed by the briefing of the techniques used to analyze the data.

\section{Population and Sample:}

The target population of the study was the Egyptian entrepreneurs and owner-managers of the Egyptian large, medium, small and micro business. A combination of convenience and judgemental sampling techniques were used as is frequently done in entrepreneurship research (Karimi, et al., 2017; Aloulou, 2016; Linan and Chen, 2009). The total sample size was (607) classified as follows: Entrepreneurs (18.5 \%), Small business Owner-managers (39.7\%) and Micro business owner-managers (41.8\%). The percentage of male (93\%) and of female (7\%). The research sample covered several economic activities and represented the Egyptian industrial cities and small and micro business compounds.

\section{Data Collection:}

To test the research hypotheses, the researcher used a 54-item self-administrated questionnaire. Originally, the questionnaire was developed and adapted depending on the scales used in the previous studies as mensioned before. Each item was rated on a five-point Likert scale (1= strongly disagree to 5= strongly agree). The questionnaire consisted of both positively and negatively framed questions, which were inter- 
mingled to minimize the response set bias. Responses were coded in such a manner that higher mean scores represented higher internal locus of control, higher level of independence, hiegher level of wealth valuation, greater innovativeness, hiegher tendency for networking, hiegher motive for achievement, higher propensity to take risk, and higher propensity to optimism. Other than the information on entrepreneurial eight psychological traits, information on demographic profile (size of business and gender) of the respondents was also collected. The last part of the questionnaire includes the personal information about the respondants.

To raise the response rate, the researcher depended on the personal interviews with Egyptian entrepreneurs and small and mcro business owner-managers. Besides, the questionnaire was, also, sending by e-mails and surveymonkey site.

\section{Conclusion:}

Data analysis began with correlation analysis. Table (2) indicates that correlation between research variables is moderated. The correlation coeffecients indicate that all the relationships are significant exept for the relationships between (owners - wealth) and (owners - networking). The correlation coeffecients indicate that all the relationships are positive exept for the relationships between (autonomy-LOC), (autonomy-owners) and (autonomy-LOC).

Table (2): Correlation Analysis and Relaiability Coffecients

\begin{tabular}{|c|c|c|c|c|c|c|c|c|c|}
\hline Variables & Mean & S.D. & Wealth & Innovation & Network & Optimism & Autonomy & $\mathrm{LOC}$ & Owners \\
\hline Wealth & 19.556 & 4.876 & $(0.720)$ & & & & & & \\
\hline Innovation & 12.805 & 1.898 & $0.267^{* * *}$ & $(0.739)$ & & & & & \\
\hline Network & 12.866 & 1.973 & $0.183^{* * *}$ & $0.465^{* * *}$ & $(0.683)$ & & & & \\
\hline Optimism & 15.556 & 2.469 & $0.254^{* * *}$ & $0.317^{* * *}$ & $0.297^{* * *}$ & $(0.535)$ & & & \\
\hline Autonomy & 10.719 & 2.765 & $0.360^{* * *}$ & $0.082^{*}$ & $0.122^{* *}$ & $0.118^{* *}$ & $(0.606)$ & & \\
\hline $\mathrm{LOC}$ & 10.316 & 2.620 & $-0.099^{*}$ & $0.114^{* *}$ & $0.105^{* *}$ & $0.107^{* *}$ & $-0.159^{* *}$ & $(0.585)$ & \\
\hline Owners & 0.766 & 0.741 & 0.034 & $0.086^{*}$ & 0.018 & 0.089* & $-0.082^{*}$ & $0.118^{* * *}$ & - \\
\hline
\end{tabular}

$* p<0.05 \quad * * p<0.01 \quad{ }^{* * *} p<0.001 \quad$ Source: Prepared by researcher using SPSS (23)

MANOVA analysis was conducted to identify the significance differences of entrepreneurial traits according to owners (owner-managers and entrepreneuers). MANOVA results indicate that there are significanct differences among entrepreneurial traits regarding business owners $(F=2.900, P<0.001)$. Specifically, Table (3) indicates that wealth $(F=3.486, P<0.05)$, autonomy $(F=4.001, P<0.05), L O C(F=7.541, P<0.001)$, and optimism $(\mathrm{F}=2.479, \mathrm{P}<0.1)$, differentiate significantly among Egyptian owner-managers of micro and small business and entrepreneurs. Innovation and networking were not significant.

For wealth, LOC and Optimism, means have been raised towards Egyptian entrepreneurs. For autonomy, means have been raised towards Egyptian micro business owner-managers. These results, generally, support $\mathrm{H} 1, \mathrm{H} 4, \mathrm{H} 5$ and $\mathrm{H} 6$, but there was no support for $\mathrm{H} 2$ Table (3): MANOVA Results

\begin{tabular}{|c|c|c|c|c|c|c|c|c|}
\hline \multirow{2}{*}{$\begin{array}{c}\text { Entrepreneurial } \\
\text { Traits }\end{array}$} & \multicolumn{2}{|c|}{$\begin{array}{c}\text { Owner-managers } \\
(\text { Micro }=254)\end{array}$} & \multicolumn{2}{|c|}{$\begin{array}{l}\text { Owner-managers } \\
(\text { Small=241) }\end{array}$} & \multicolumn{2}{|c|}{$\begin{array}{c}\text { Entrepreneurs } \\
(112) \\
\end{array}$} & \multirow[t]{2}{*}{$\begin{array}{l}\text { MANOVA } \\
\text { (F values) }\end{array}$} & \multirow[t]{2}{*}{$\mathbf{R}^{2}$} \\
\hline & Mean & S. D. & Mean & S. D. & Mean & S.D. & & \\
\hline Wealth & 19.665 & & & & & & & \\
\hline Innovation & 12.646 & 2.026 & 12.838 & 1.817 & 13.098 & 1.740 & $479 *$ & 0.005 \\
\hline Network & 12.827 & 2.061 & 12.884 & 1.900 & 12.920 & 1.941 & $4.001^{* *}$ & 0.010 \\
\hline Optimism & 15.347 & 2.615 & 15.589 & 2.231 & 15.964 & 2.585 & $7.541^{* * * *}$ & 0.021 \\
\hline Autonomy & 11.079 & 2.735 & 10.386 & 2.776 & 10.625 & 2.738 & 2.278 & 0.004 \\
\hline $\mathrm{LOC}$ & 9.957 & 2.677 & 10.332 & 2.385 & 11.098 & 2.819 & 0.101 & 0.003 \\
\hline
\end{tabular}
and $\mathrm{H} 3$.

As the independent variables of this research are ordinal variables, it is necessary to identify the sources of significant differences among the significant dependent variables (entrepreneurial traits). The ultimate 
objective is to identify the intervals responsible for the significance. The Post Hoc Multiple Comparisons (LSD) results indicate the following:

- The significance of "wealth" with business owners is related to the significant difference exists between entrepreneurs and small business Owner-managers. Entreprenurs have hiegher tendencies to wealth than small business Owner-managers.

- The significance of "autonomy" with business owners is related to the significant difference exists between Owner-managers of micro and small business. Owner-managers of micro business have hiegher tendencies to autonomy than small business Owner-managers.

- The significance of "LOC" with business owners is related to the significant difference exists between entrepreneurs and both of micro and small business Owner-managers respectively. Entreprenurs have hiegher tendencies to LOC than both of micro and small business Owner-managers.

- The significance of "optimism" with business owners is related to the significant difference exists between entrepreneurs and micro business Owner-managers. Entreprenurs have hiegher tendencies to optimism than micro business Owner-managers.

\section{Discussion and Implications}

The focus of this article was on the personal views of entrepreneurs, so it adopted the trait model of entrepreneurship. Although the literature presents evidence for small and medium sized firms, this topic is under-studied in the micro firm context. Accordingly, the present study sought to determine how Egyptian entrepreneurs are different from micro and small business owner-managers regarding the entrepreneurial characteristics they possess.

The study results suggest that the traits of wealth valuation, innovativeness, networking, optimism, autonomy and locus of control (LOC), respectively, were capable to differentiate the Egyptian entrepreneurs and owner-managers. In other words, Egyptian entreprenuers and owner-managers were found to be wealth oriented, more innovative, effective networkers, displayed high level of independence, optimistics and had internal locus of control.

The findings emerging from this study present, partially, a contrast to the stereotypical image of the entrepreneur in the western environment. These findings ensured that the Egyptian entrepreneurs and owner-managers are function of their business environment. As Bygrave (1989) has stated, "entrepreneurs cannot be separated from their environments". In concrete terms, the characteristics of "wealth valuation", "networking" and "optimism" were the least among the entrepreneurial characteristics to be investigated in the western studies. The researcher rationale was to investigate these characteristics as he expected to be the most differentiated characteristics in the Egyptian context. The results support this rationale and these three characteristics were among the first characteristics distinguishing the Egyptian entrepreneurs and owner-managers.

The assumption that people start new ventures to increase their personal wealth underlies much of the research in entrepreneurship. The goal of personal wealth is assumed paramount. Thus, the terms "wealth" and "entrepreneurship" are inextricably linked in the minds of many people, including researchers, in capitalist societies (Amit, et al., 2000). Our findings support the idea of "money matters", i.e. money (for Egyptian entrepreneurs and owner-managrers) is the only, or even the most important, motive for entrepreneurship and for entrepreneurs' decisions to start new ventures.

On the empirical research, economic motivation often appears lower in relation to other objectives. Davidsson (1989) refers to several studies which show that other goals, beside profit expansion, 
are wanted. This situation seems true, especially, to established businesses. It is, also, admited that, in early development phases, economic motivation may completely dominate behaviour while other objectives may be sacrificed as a consequence to profit prosecution (Raposo et al., 2008). This was in line with several previous studies which investigated the personality traits of entrepreneurs (e.g.: Gurol and Atsan, 2006; Amit et al., 2000; Koh, 1996; Robinson et al., 1991).

Along with wealth valuation, it is reasonable to expect that people with a favorable attitude toward social networking would be more likely to engage in business startup behaviour. Accordingly, social networking or the ability to build social relationships is the underlying activity which is important to succeeding in the Egyptian context. Egyptian entrepreneurs used networking to facilitate their business activities, to access information, to get advice and to solve business and governmental problems. As a result, no significant differences were expected for this variable among Egyptian entrepreneurs and owner-managers. Theses results agreed with idea stated by (O'donnell et al., 2001) that the entrepreneurs place great importance on meeting and conversing with people, leading to the belief that "Business Know Who" is at least as important as "Business Know How".

The empirical literature represents similar results in China. Social networking is one of the major behavioral activities of Chinese society and is an essential component of what is called "Guanxi". Guanxi involves building personal relationships and is used to overcome hardships and to attain both personal and business gains (Taormina and Lao, 2007).

Several researchers have discussed the role of optimism as a motive force accounting for persistence and commitment. Optimism has also been a negative force among entrepreneurs resulting in their tendency to create ventures with a high risk of failure. Optimism as it is discussed in entrepreneurship literature is like "dispositional optimism" in psychology, which represents biases held, across time and situations, positive expectations (Liang and Dunn, 2015).

Although this trait represents a positive aspect of the personality of the Egyptian entrepreneurs and owner-managers, it does not represent the real facet of the Egyptian personality in general, and the Egyptian entrepreneurial personality, in specific. The Egyptian entrepreneurial personality is pessimistic. We can note this fact, obviously, from the continuous complants from the prevailing situation, on one side, and from the governmental and legal obsticales hindering investment, on the other side.

These three traits reflect the realistic and paragmatic nature of the Egyptian entrepreneurs and owner-managers personality. The researcher considers the three aforemensioned traits are very representative of the Egyptian entrepreneurial personaliy. This why he stated that results of this study, partially, go along with the results of the western literature. However, the other three traits of our model (Innovateveness, Independence and Locus of control) are representative outputs of the entrepreneurial personality in western entrepreneurial literature. So, it is not surprised to represent the Egyptian entrepreneurial personality as well.

In addition, the study results suggest that the traits of wealth valuation, optimism, Independence and locus of control (LOC) were significant in differentiating the Egyptian entrepreneurs and owner-managers. The sources of this differentiation account for Egyptian entrepreneurs against micro and small business owner-managers for: wealth valuation, optimism, and locus of control. That is Egyptian entrepreneurs were wealth oriented, optimistics and enjoy enternal locus of control comperative to Egyptian micro and small business owner-managers. Independence was the exception. The source of Independence accounts for Egyptian micro business owner-managers against small business owner-managers. That is Egyptian micro business owner-managers exhibit high level of independence than small business owner-managers. 
These findings logically coincide with the differences in the goals of small business owners and entrepreneurs. Both of entrepreneurs and owner-managers have goals that are related to their personalities. Entrepreneurs exhibit the psychological profile that is consistent with their goals of growth and profit, and with the use of systematic planning. Alternatively, the psychological predispositions and actions of small business owners are more attuned to their personal goals and family income (Stewart, Jr., et al., 1998).

Although the purpose of this research was primarily to test theory, the results have important implications for theory development in entrepreneurship. The findings reinforce the differentiation that is made between small business management and entrepreneurship. Also, I think that the findings of this study have to be considered as inputs for entrepreneurial policies in the Egyptian context and have to be considered in the design of entrepreneurial education programs in the Egyptian universities.

\section{Conclusion:}

Since the sampling frame of the population considered was not available, the researcher used a combination of convenience and judgemental sampling techniques. This means that the sample elements are not necessarily representative of the target population, especially for the Egyptian entrepreneurs.

In addition, the researcher used the following constructs interchangeably: Auronomy/ Independence, Social Network/ Personal Network and Wealth Valuation/ Profit maximization.

The results of this study point to a need to portray a more comprehensive framework of the entrepreneurial attitudes, orientations and behaviours of the Egyptian entrepreneurs and business owners. There is a room to differentiate and compare the characteristics of Egyptian entrepreneurs with that of Egyptian managers or intrapreneurs. There is, also, an interesting chance to differentiate the entrepreneurial traits of Egyptian entrepreneurs and women entrepreneurs. It may be possible to examine these traits among the family and non-family entreprneurs.

Studies can be designed to examine the predictive power of these six psychological traits in relation to other entrepreneurial issues. For example, they can be used as potential predictors (antecedents) of entrepreneurial intentions. They can, also, be treated as influencers of the entrepreneurial success of the SMEs in the Egyptian business context. 


\section{References}

Abdelbary, A. (2019). SMEs Sector: A Key Driver to The Egyptian Economic Development, https://ssrn.com/abstract $=3334845$

- $\quad$ Abou Elseoud, M. S; F. M. Kreishan and M. A. M. Ali. (2019). “The Reality of SMEs in Arab Nations: Experience of Egypt, Jordan and Bahrain", Journal of Islamic Financial Studies, 5 (2): 110-126.

Achy, L. and R. Selim. (2017). "Micro and Small Enterprises in Egypt", The 23' ${ }^{\text {rd }}$ ERF Annual Conference, March 1-24.

- $\quad$ Adomako, S. A.; D. M. Uddin and O. Damoah. (2016). “Entrepreneurs' Optimism, Cognitive Style and Persistence", International/ournal of Entrepreneurial Behavior \& Research, 22 (1):84-108.

- $\quad$ Aloulou, W. J. (2016). "Predicting Entrepreneurial Intentions of Final year Saudi University Business Students by Applying The Theory of Planned Behavior", Journal of Small Business and Enterprise Development, 23 (4):1142-1164.

- Amit, R.; K. R., Maccrimmon; C. Zietsma and J. M. Oesch. (2000). “Does Money Matter?: Wealth Attainment as the Motive for Initiating Growth -oriented Technology Ventures", Journal of Business Venturing 16 (2): 119-143.

- $\quad$ Ayadi, R. and E. Sessa. (2017). "Micro, Small and Medium Sized Enterprises Development in Egypt, Jordan, Moroco and Tunisia: Structure, Obstecles and Policies", EMNES Studies, 3, Dec., 1-88.

- $\quad$ Beaver, G. and P. Jennings. (2005). “Competitive Advantage and Entrepreneurial Power: The Dark Side of Entrepreneurship", Journal of Small Business and Enterprise Development, 12 (1): 9-23.

- $\quad$ Begley, T. M. and D. P. Boyd. (1987). "Psychological Characteristics Associated with Performance in Entrepreneurial Firms and Smaller Business", Journal of Business Venturing, 2 (1):79-93.

- $\quad$ Bertelsen, R. G.; S. Ashourizadeh; K. W. Jensen; T. Schøtt and Y. Cheng. (2017). “Networks Around Entrepreneurs: Gendering in China and Countries Around The Persian Gulf", Gender in Management: An International Journal, 32 (4): 268-280.

- Brockhaus, R. H. (1980). "Risk Taking Propensity of Entrepreur", Academy of Management Journal, 23 (3): 509-520.

- $\quad$ Bygrave, W. D. and C. W. Hofer. (1991). "Theorizing About Entrepreneurship", Entrepreneurship Theory and Practice 16 (2):13-22.

- $\quad$ Bygrave, W.D. (1989). "The Entrepreneurship Paradigm (II): Chaos and Catastrophes Among Quantum Jumps?", Entrepreneurship: Theory \& Practice, 14 (2): 7-30.

- $\quad$ Carland, J. W.; F. Hoy; W. R. Boulton and J. A. Carland. (1984). “Differentiating Entrepreneurs from Small Business Owners", Academy of Management Journal, 9 (2): 354-359.

- Central Agency for Public Mobilization and Statistics (CAPMAS). (2018). Statistical Yearbook, Egypt, https://www. capmas.gov.eg/Pages/StaticPages.aspx?page_id=5034.

- Chatterjee, N. and N. Das. (2015). “Key Psychological Factors As Predictors of Entrepreneurial Success: A Conceptual Framework", Academy of Entrepreneurship Journal, 21 (1): 102- 114.

- $\quad$ Chatterjee, N.; N. Das and N. K. Srivastava. (2019). "A Structural Model Assessing Key Factors Affecting Women's Entrepreneurial Success: Evidence from India", Journal of Entrepreneurship in Emerging Economies, 11 (1): pp. 122-151.

- Chaudhary, R. (2017). “Demographic Factors, Personality and Entrepreneurial Inclination: A Study among Indian University students", Education + Training, 59 (2): 171-187.

- Creative Associates International. (2014). "Micro, Small and Medium Enterprises in Egypt, Entrepreneurship", Business Procedures and Value Chain Analysis, August, 1-87. 
Cyr, A.; O. Meier and J. C. Pacitto. (2011). "Method in Their Madness: Understanding the Behaviour of VSE Owner-managers", Journal of Small Business and Enterprise Development, 18 (2): 331 351.

Davidsson P. (1995). “Determinants of Entrepreneurial Intentions", The RENT IX Workshop, Piacenza, Italy, Nov. 23-24.

- Dinis A.; A. Paço; J. Ferreira; M. Raposo; R. G. Rodrigues (2013). “Psychological Characteristics and Entrepreneurial Intentions among Secondary Students", Education and Training, 55 (8/9):763-780.

- Ebbers, J. J. (2013). “Networking Behavior and Contracting Relationships among Entrepreneurs in Business Incubators", Entrepreneurship Theory and Practice, 38 (5): 1-23.

- $\quad$ Entrialgo, M.; E. Fernandez and C. J. Vazquez. (2000). “Psychological Characteristics and Process: The Role of Entrepreneurship in Spanish SMEs", European Journal of Innovation Management, 3 (3): 137-149.

- Gartner, W. B. (1988). "Who Is an Entrepreneur? Is the Wrong Question", American Journal of Small Business, 12 (4): 11-32?

Gherhes, C.; N. Williams; T. Vorley and A.C. Vasconcelos. (2016). “Distinguishing Micro-Businesses from SMEs: A Systematic Review of Growth Constraints", Journal of Small Business and Enterprise Development, 23 (4): 939-963.

- Gilmore, A.; D. Carson and A. O'Donnell. (2004). "Small Business Owner-Managers and Their Attitude to Risk", Marketing Intelligence \& Planning, (22) 3: 349-360.

- Gray, M. (1998). "Economic Reform, Privatization and Tourism in Egypt", Middle Eastern Studies, 34 (2): $91-112$.

- Greve, A. and J. W. Salaff. (2003). "Social Networks and Entrepreneurship", Entrepreneurship Theory and Practice, 28 (1): 1-22.

- Gürol, Y. and N. Atsan. (2006). “Entrepreneurial Characteristics Among University Students: Some Insights for Entrepreneurship Education and Training in Turkey", Education + Training, 48 (1): 25-38.

- Hair, Jr. J. F.; W. C. Black; B. J. Babin and R. E. Anderson. (2010). Multivariate Data Analysis. Pearson Prentice-Hall, $7^{\text {th }}$. ed.

- Haynes, P. J. (2003). “Differences among Entrepreneurs: Are You Experienced? May Be The Wrong Question", International Journal of Entrepreneurship Behaviuor and Research, 9 (3): 111-128. Henrekson, M. and T. Sanandaji. (2014). "Small Business Activity Does Not Measure Entrepreneurship", PNAS, 111 (5): 1760- 1765.

Hisrich, R.; J. Langan-Fox and S. Grant. (2007). “Entrepreneurship Research and Practice: A Call to Action for Psychology", American Psychologist, 62 (6): 575- 589.

- Ibrahim, P.A. (2018). "Growth and Structure of Micro, Small, and Medium Enterprises (MSMEs) in Kerala", Journal of Rural and Industrial Development, 6 (1): 9-17.

- Jain, R. and S. W. Ali. (2012). "Personal Characteristics of Indian Entrepreneurs and Intrapreneurs: An Empirical Study", Management and Labour Studies, 37 (4): 295-322.

- Jaouen, A. and F. Lasch. (2015). "A New Typology of Micro-Firm Owner-Managers", International Small Business Journal, 33 (4): 397- 421.

- Johnson, D.; R. Newby and J. Watson. (2003). “Discribing the Entrepreneur: How Approapriate Is the Founder/ Non-Founder Dichotomy?", The Small Enterprise Association of Australia and Newzealand $16^{\text {th }}$ Annual Conference, 23 Sept-1 Oct., Ballarat.

- Karimi, S.; H. J. A. Biemans; K. N. Mahdei; T. Lans; M. Chizari and M. Mulder. (2017). "Testing the Relationship between Personality Characteristics, Contextual Factors and Entrepreneurial Intentions in a Developing Country", International Journal of Psychology, 52 (3): 227- 240. 
Koh, H. C. (1996). "Testing Hypotheses of Entrepreneurial Characteristics: A Study of Hong Kong MBA Students", Journal of Managerial Psychology, 11 (3): 12-25.

- Kusmintarti, A.; A. Thoyib; G. Maskie and K. Ashar. (2016). "Entrepreneurial Characteristics As a Mediation of Entrepreneurial Education Influence on Entrepreneurial Intention", Journal of Entrepreneurship Education, 19 (1): 24-37.

- $\quad$ Laguir, I. and M. D. Besten. (2016). “The Influence of Entrepreneur's Personal Characteristics on MSE's Growth Through Innovation", Applied Economics, 48 (44): 4183-4200.

- Lee-Ross, D. (2015). “Personality Characteristics of The Self- employed: A Comparison Using The World Values Survey Data Set", Journal of Management Development, 34 (8):1094- 1112.

- $\quad$ Liang, C. K. and P. Dun. (2014). “Entrepreneurial Profile, Characteristics, Expectations, and Outcomes: An Empirical Study to Compare Rural Entrepreneurs with Urban Entrepreneurs", American Journal of Entrepreneurship, 7 (2): 58- 75.

- Liñán, F. and Y. W. Chen. (2009). “Development and Cross-cultural Application of a Specific Instrument to Measure Entrepreneurial Intentions", Entrepreneurship Theory and Practice, 33 (3): 593-617.

- Littunen, H. (2000). "Entrepreneurship and The Characteristics of the Entrepreneurial Personality", International Journal of Entrepreneurial Behaviour and Research, 6 (6): 295-309.

- Mabhungu, I. and B. V. Poll. (2017). "A Review of Critical Success Factors Which Drives the Performance of Micro, Small and Medium Enterprises", International Journal of Business and Management, (12) 6 : 151-164.

- Masurel, E. and E. Masurel. (2019). The Entrepreneurial Dilemma in The Life Cycle of The Small Firm. Emerald Publishing Limited.

- $\quad$ Nasip, S.; S. R. Amirul; S. L. Sondoh Jr. and G. H. Tanakinjal. (2017). “Psychological Characteristics and Entrepreneurial Intention: A Study among University Students in North Borneo, Malaysia", Education+ Training, 59 (7/8): 825-840.

- O'donnell, A.; A. Glimore; D. Cummins and D. Carson. (2001). “The Network Construct in Entrepreneurship Research: A Review and Critique", Management Decision, 39 (9): 749- 760.

- Obschonka, M. and M. Stuetzer. (2017). “Integrating Psychological Approaches to Entrepreneurship: The Entrepreneurial Personality System (EPS)", Small Business Economics, 49 (1): 203-231.

- Omorede, A.; S. Thorgren and J. Wincent. (2015). "Entrepreneurship Psychology: A Review", International Entrepreneurial Management Journal, 11 (4): $743-768$.

- $\quad$ Ong, J. W. and H. B. Ismail. (2012). “Entrepreneurial Traits and Firm Serendipity-Seeking on SMES' Performance: The Effect of Firm Size", Journal of Enterprising Culture, 20(3): 265-286.

- Pedrini, M.; V. Langella and M. Molteni. (2017). “Do Entrepreneurial Education Programs Impact The Antecedents of Entrepreneurial Intention? An Analysis of An Entrepreneurship MBA in Ghana", Journal of Enterprising Communities: People and Places in the Global Economy, 11 (3): 373-392.

- $\quad$ Pillis, E. D. and K. K. Reardon. (2007). "The Influence of Personality Traits and Persuasive Messages on Entrepreneurial Intention: A Cross-Cultural Comparison", Career Development International, 12 (4): 382- 396.

- $\quad$ Raposo, M.; Paco, D. A. and J. Ferreira. (2008). “Entrepreneur's Profile: A Taxonomy of Attributes and Motivations of University Students", Journal of Small Business and Enterprise development, 15 (2): 405-418.

- $\quad$ Rauch, A. and M. Frese. (2007). “Let's Put The Person Back Into Entrepreneurship Research: A Meta Analysis on The Relationship between Business Owners' Personality Traits, Business Creation, and Success", European Journal of Work and Organizational Psychology, 16 (4): 353-385. 
- $\quad$ Robinson, P. B.; D. V. Stimpson; J. C., Huefner and H. K. Hunt. (1991). An Attitude Approach to the Prediction of Entrepreneurship", Entrepreneurship Theory and Practice, 15 (4):13-31.

- $\quad$ Sjgren, H.; K. Puumalainen and P. Syrja. (2011). "What Does the Owner-manager Want and Get Out of The Business?", International Journal of Law and Management, 53 ( 5): 355-374.

- $\quad$ Smith, R.; R. Bell; H. Watts. (2014). “Personality Trait Differences between Traditional and Social Entrepreneurs", Social Enterprise Journal, 10 (3): 200-221.

- Stewart, Jr. W. H.; W. E. Watson; J. C. Carland and J. W. Carland. (1998). “A Proclivity for Entrepreneurship: A Comparison of Entrepreneurs, Small Business Owners, and Corporate Managers", Journal of Business Venturing, 14 (20): 189-214.

- $\quad$ Taormina, R. J and S. M. Lao. (2007). "Measuring Chinese Entrepreneurial Motivation Personality and Environmental Influences", International Journal of Entrepreneurial Behaviour and Research, 13 (4): pp. 200-221.

- Thomas, A. S. and S. L. Mueller. (2000). “A Case for Comparative Entrepreneurship: Assessing the Relevance of Culture", Journal of International Business Studies, 31 (2): 287- 301.

- Trevelyan, R. (2008). “Optimism, Overconfidence and Entrepreneurial Activity”, Mnanagement Decision, 46 (7): 986-1001.

- Turner, S. and A. Endres. (2017). “Strategies for Enhancing Small-business Owners' Success Rates”, International Journal of Applied Management and Technology, 16 (1): 34-49.

- Wang, Y. (2016). "What Are the Biggest Obstacles to Growth of SMEs in Developing Countries? An Empirical Evidence from An Enterprise Survey", Borsa Istanbul Review, 16 (3): 167-76.

- Zaki, H. M. and N. T. Zeini. (2019). Descriptive Analysis of the Entrepreneurship Ecosystem in Egypt From A Start-up Perspective: Challenges and Opportunities. EMNES Working Paper No. 24: 1-35. 
